\title{
Soft Tissue Sarcoma of the Trunk and Extremities pT2 TNM Finding v8
}

National Cancer Institute

\section{Source}

National Cancer Institute. Soft Tissue Sarcoma of the Trunk and Extremities pT2 TNM

Finding v8. NCI Thesaurus. Code C136686.

Soft tissue sarcoma of the trunk and extremities with tumor measuring more than $5 \mathrm{~cm}$ and less than or equal to $10 \mathrm{~cm}$ in greatest dimension. (from AJCC 8th Ed.) 